Canadian University Music Review

Revue de musique des universités canadiennes

\title{
Winthrop: The Work, the Theme, the Story
}

\section{Istvan Anhalt}

Numéro 4, 1983

URI : https://id.erudit.org/iderudit/1013902ar

DOI : https://doi.org/10.7202/1013902ar

Aller au sommaire du numéro

Éditeur(s)

Canadian University Music Society / Société de musique des universités

canadiennes

ISSN

0710-0353 (imprimé)

2291-2436 (numérique)

Découvrir la revue

Citer cet article

Anhalt, I. (1983). Winthrop: The Work, the Theme, the Story. Canadian

University Music Review / Revue de musique des universités canadiennes, (4),

184-195. https://doi.org/10.7202/1013902ar

(c) Canadian University Music Society / Société de musique des universités canadiennes, 1983
Ce document est protégé par la loi sur le droit d'auteur. L’utilisation des services d'Érudit (y compris la reproduction) est assujettie à sa politique d'utilisation que vous pouvez consulter en ligne.

https://apropos.erudit.org/fr/usagers/politique-dutilisation/ 


\title{
WINTHROP: THE WORK, THE THEME, THE STORY
}

\author{
Istvan Anhalt
}

Winthrop is a major new musico-dramatic work by Istvan Anhalt. In view of the theme and character of his earlier La Tourangelle (completed in 1975; published by Berandol, 1982) the two works can, and probably ought to be, seen as parallel compositions, forming a large-scale diptych that probes two of Canada's most important roots, reaching back into the first half of the seventeenth century. In La Tourangelle Anhalt chose for the focal personage Marie de l'Incarnation, the Ursuline nun who became a very significant figure in the history of La Nouvelle France. In Winthrop he aims at depicting the life and times of John Winthrop, the first governor of the Massachusetts Bay Company who resided on the North American continent, taking into account events and experiences that took place before, during, and after his emigration to New England.

-Editor

\section{The Work*}

Winthrop is an opera (in the manner of an historical pageant) in two parts, with a total duration of about two and one-half hours. Completed in March 1983, it is scored for six solo singers, a mixed choir of at least twenty-four voices, a small boys' choir, and an instrumental ensemble of at least thirty players. I assembled the text myself, relying principally on original sources from the first half of the seventeenth century, but borrowing also from others that date from earlier and from more recent periods. I completed the libretto by adding, here and there, a few passages, as the need for these arose, and whenever no suitable "authentic" text was at hand.

* This account does not aim at reflecting on the various stages of the compositional process, but wishes only to give an idea of certain aspects and details of the final result. 


\section{The Theme}

The central figure of the piece is John Winthrop, governor of the Massachusetts Bay Company, the founder of Boston, the most commanding figure in the history of New England from 1630 to 1649 . Winthrop was born in England, lived and died an Englishman, yet he was also a major contributor to the evolution of what might be called the "New England mind," and, by extension, also the "English-Canadian mind." (A claim that John Winthrop might be considered a founding father of Canada also would have to-and I think does-rest on the evidence of the vital role Massachusetts, and other parts of New England, played in the history of Nova Scotia and Lower and Upper Canada before, during, and after the American Revolution.)

In addition to the genetic legacy, Winthrop, members of his original group, and their descendants left also a spiritual one, which is shared to this very day by large segments of the Englishspeaking societies in the United States and Canada: it is what one may call the Puritan ethic, or world-view. This inheritance is a recognizable component in the lives of many men and women who have significantly contributed to the evolving North American experience as individuals, and at times also, as members of diverse institutions, in an uninterrupted flow ever since John Winthrop's time.

But John Winthrop is still more than an outstanding historical personage, a founding father, and a paradigm for an ethicalphilosophical outlook. He is remembered also, and foremostly, as a human being, somewhat larger in certain dimensions than most, yet identifiable as such in his passions, striving, gropings, doubts, triumphs, failures, and his compromises. Only when one is able to regard him from this viewpoint, can one begin to understand him in his public roles and feel with him in his actions. When coming to know him in this manner, one begins to sense that through the life of this man one might also have gained a glimpse into the universal human condition. It is the aim of Winthrop to bring about a synthesis of representations of private and public worlds, of times past and present, of historical events, and of some of the complex currents of ideas and feelings underlying them, for the purpose of creating a framework for such a kind of understanding. 


\section{The Story \\ (A Synopsis)}

\section{PART ONE}

\section{Pilgrimage and Discovery}

A pastoral scene near Groton, in Suffolk, England. It is a beautiful summer afternoon, in the present. One hears the sounds of distant bells. A man and woman are heard talking: inward monologues ... and an elliptical conversation. The pull of the past is felt and is constantly increasing. Memory images float by . . . A dreamy state of mind, a feeling of déjà vu, takes hold . . . The attraction of "roots" is becoming irresistible ... Memory layers long dormant, or perhaps never tapped before, come to life gradually, activated by sights, sounds, and by other aspects of the general ambience. Hardly legible inscriptions on tombstones draw attention to the Winthrop family, members of a clan of strivers from the North. Their upward struggle is remembered and briefly, but vividly, re-enacted, culminating in the sudden appearance of a royal messenger conferring rights and privileges on an Adam Winthrop for services rendered to the King. The past and present constantly and simultaneously tug and pull the hearer/viewer ... One is uncertain whether one is awake, dreams, imagines, or is actually transported back into a living past ... The latter wins out ... The present fades away and one hears the announcement of the birth of a John Winthrop; the year is 1587 .

\section{Young John}

This is an aria that shows the transformation of a confused adolescent into a young adult who has managed to achieve a certain measure of control over himself.

One first sees/hears the young John Winthrop (a lyric tenor) as an early seventeenth-century type of rock singer, overflowing with energy and passion. The music is powerful, athletic, expressed through large gestures, and is indicative of a strong inner drive that pushes him onwards, close to the edge of seeming insanity. He first sings using a kind of scat language (vintage, say, of anno 1603). One senses in his delivery very considerable physical and mental powers which are, as yet, incapable of being manifested in a rational way. When the first intelligible words are formed they speak of a sense of guilt felt over sexual urges. 
Two groups of singers comment on this scene (they gradually emerge from a dark background): the first is that of nine to fifteen younger boys who comment with empathy in a counterpoint imitating psalmody; the other group consists of women who are horrified by, yet attracted to, the tribulations of the young Winthrop. They utter, in brief bursts, various prayer formulas, as well as other kinds of complementary material.

Very gradually young John gains understanding and a degree of maturity. The aria ends with an impassioned pledge.

\section{John and Margaret}

This is an intimate dialogue between Winthrop and his young wife: a love duet. It is alternately tender, affectionately passionate, and tender again. It depicts the two in a clearly expressed relationship, that acknowledges roles, reciprocal responsibility, and a high level of mutual support.

The scene is witnessed from a distance by small groups of men and women, who, in places, echo what John and Margaret are conveying to each other.

\section{Famous Brittany}

This section depicts the turbulent socio-political situation in Britain that led to Winthrop's emigration to America and to the revolution that caused the demise of Charles I and Cromwell's ascent to power. At another level, it is a paradigm of any struggle for socio-political power, and related human group behavior, that causes events to occur, and is being buffeted by them.

The scene could be that of a fair-ground, a kaleidoscopic representation of society. A brief orchestral introduction depicts turmoil, dissatisfaction, suppressed hostility, passion and brutality, engendered by conflicting forces and feelings.

This is interrupted by the first vocal sounds: "Call to mind!" This alarm signal refers to certain dangers menacing church and state. In response a frantic action erupts. Contending groups sing and shout words at each other indicative of various and opposing attitudes and beliefs; a choral battle takes place. This gradually degenerates into a frightened, forced half-whisper, broken by silences. Fear takes hold of all, subsequently giving way to growing anger. The next attitude broadcasts, at an always more and more excited level, prejudices in the form of political/ moral slogans. After these the center of attention shifts to a group of women who utter a series of curses, culminating in 
hate-filled sneers. A group of urchins laugh at the goings-on. Some men begin to intone what sounds like a patriotic hymn, which they belt out, drawing others along with them. One is uncertain how much of this is an expression of conviction, how much mockery, or perhaps both, simultaneously. The boys, for certain, are having a good time of it: they repeatedly punctuate the proceedings with bursts of loud laughter.

A sudden break occurs: one hears the music of a village band, a kind of quick polka. To its tune a small group of women recite/intone the words of a ballad, which in their interpretation takes on the character of a bawdy song.

The stern voice of a preacher is heard next, warning of religious deviation. He is sustained by responses of a group of frightened faithful. The specter of Judgment Day is evoked ...

But there is hope in all this confusion and gloom. It is offered by another voice: that of a herald, who speaks of a haven and of a new life to be found overseas, in America. He is really a promoter of emigration, a proto-adman, who seems to believe in what he advocates. He speaks and sings with rising passion, describing the alleged riches as well as the spiritual salvation a New England holds in store for all. His delivery is infectious and he carries the crowd with him into an enthusiastic outburst of agreement and pledge.

The scene accelerates musically and is accompanied by a rapid visual fade-out, preparing the way for the next section and scene.

\section{Call and Response}

This section enacts events that took place during the period 1628-30.

At the outset, Margaret, in her study (or parlor), reads (sings) aloud passages from a letter of John Winthrop, written from London. We hear the description (eye-witness or close approximation thereof) of one of the most significant and dramatic scenes in seventeenth-century British parliamentary history. We imagine, or may actually see, through projections on a backdrop, the fateful events that set into motion momentous political changes in Britain as well as in America.

The next sub-scene shows Winthrop in deep thought debating the pros and cons of emigrating to the New World. The leading voice now is that of the middle-aged Winthrop (a baritone), but during this interior debate the young Winthrop (a tenor) takes 
the other part. As the decision to go to America appears to become the preferred one, groups of men and women join in, supporting this choice. They reach a certain point of enthusiasm which suddenly gives way to the next sub-scene.

This is the oath-ceremony. Winthrop is, in short order, elected governor of the newly formed Massachusetts Bay Company, and takes the governor's oath in the course of which one sees/hears him transformed into a forceful leader, who has no more doubts about his mission.

The next sub-scene depicts the busy goings-on (there is so little time left before the designated departure date) during the preparations for the voyage and emigration of about one thousand persons. Men, and women rush around storing and packing various goods and provisions...

The preceding activity comes to an abrupt end: a new subscene begins. We are in a port, ships are seen, and farewells are being said. The atmosphere is solemn, and quietly emotional. Promises are being made, support and forgiveness are sought. The three ships glide out of the harbor ... the wind gets into the sails... echoes of the farewell mix with sounds of the sea ... the sounds fade out as the ships disappear from sight.

\section{PART TWO}

\section{Covenant and Lesson (The Voyage)}

The scene: on board Winthrop's flag-ship, the Arbella, on the high seas, on the way to America.

The protagonists: a look-out, who is the "eye" of the ship, high on a mast (sung by the young Winthrop) and the governor (the middle-aged Winthrop) who is the "brains" of the group, the leader. They are complemented by a group of boys who are given instruction in catechism and by groups of men and women in various roles.

The first vocal sound we hear is the first announcement of the look-out; focus on the environment.

This is followed by a dialogue between governor Winthrop and a group of men as they outline the terms of a covenant. Inward focussing: "A Citty upon a Hill we shall be."

The second announcement of the look-out.

Antiphonal exchange between Winthrop and the boys: the catechism.

Women join in with a pledge: "I do believe with my heart ... etc." "A Citty upon a Hill we shall be." 
Boys begin a dream-like description of this "Citty." Their fantasy carries along the entire group whose communal song reaches an ecstatic level.

The third, excited, intervention of the look-out announces the sighting of land. This breaks the spell of the preceding fantasy, and engages every person on board in a free-for-all outburst. Slowly the shores of the "New World" come into sight. A great sense of expectation descends upon the group as men probe the depths for a landing ... A final promise is voiced about co-operation ... The land nears . . . the voices on the ship fall silent... From the distance one faintly hears the steady throbbing of a deep drum ... the heart-beat, or voice, of an unknown world perhaps ... The ending of the section is tinged with a sense of foreboding that contrasts with the series of moods experienced during the voyage.

\section{Boston .... a Citty}

There is no break between the preceding section and this one. The distant drumming continues... a great hush and immobility persist on the ship as reality sinks in: America appears, from this vantage point at least, as an immense jungle, containing little promise, but much threat. The mood swings to instant despair, expressed in the words: "We all die in Boston," and other similar expressions.

This section spans about six years and tells of various episodes that highlighted the history of Boston during the years 1630-36. From the first hours of landing the story leads to the political crisis caused by Mrs. Anne Hutchinson, who challenged Winthrop and the ruling group for power in 1636.

The initial sub-scene develops into near munity on the very shores of the unknown territory. This mood of defeatism, engendered by fear, is successfully challenged by another attitude, calling everyone to work. We indeed see the community exerting a great effort in building the new town, Boston.

Interruption: sudden announcement of a harsh punishment, the first indication of certain judicial standards and practices in the community.

Work resumes: another interruption tells of further punishments.

Focus on the Court, and the way "law and order" is maintained in this frontier town. One senses the clash between those in power and those who do not benefit of the same in equal measure. 
A considerable degree of tension is building up through choral and scenic action.

The tension rapidly dissipates, giving place to a call (by Winthrop) for public thanksgiving. Winthrop reveals his personally compassionate attitude in socio-economic matters.

Interruption by the cries: "Fire," "A house on fire." An accident? Or arson, perhaps? Both are possible. The tension returns.

The distant drumming (which faintly persisted in the background during all the preceding sub-events) now comes into the foreground. We see the arrival of a group of Indian visitors to Boston. Their attire, and their music has little that is authentic to them. They appear as presumably seen/heard by the Bostonians of the time: either as noble savages, or as children, or as incomprehensible beings, to be feared, to be mistrusted, and perhaps also ridiculed.

The next sub-scene takes over from the preceding one: the colony's soldiers train in the distance, in the dusk ... One hears faintly the sound of military drums, trumpets, and pounding feet ... fade-out.

Someone (it turns out to be Anne Hutchinson) asks a key (and fateful) question, "What is the nature of grace?" which within a short time-span will come close to tearing apart the colony. A group responds to it by citing names of ships, implying that the answer lies in the direction of "good works." This causes the eruption of an impassioned choral debate between groups holding contrary opinions about the issue.

A sudden break follows, caused by the announcement of the violent death of a white man (John Oldham), allegedly killed by some Indians. The focus of passions abruptly changes. Calls for revenge are shouted.

More bad news: the plague has hit Boston. Chant: "We fear the plague in Boston."

Return to the concern of revenge for the death of John Oldham. The bloody deeds of a punitive expedition, the massacre of an entire Indian settlement, are enacted. We hear the sounds of dying women and men...

Back to the interior concerns of Boston: an account of harsh punishment meted out for an assortment of unlawful behavior. The level of repression and tension reaches a high pitch ... One feels the need for some kind of remedial action in the colony. But what we hear now is the voice of a young town-crier announc- 
ing three times (at various locations, backstage): "The twelfth day of the month a day of humiliation, to entreat the help of God". A mood of foreboding, marking for time ... a sense of crisis hangs in the air ... Without a break an orchestral ostinato leads to the next section.

\section{A Crisis}

One finds Winthrop (baritone) alone, thinking of the grave situation in which his colony finds itself, as a result of the political polarization caused by the activities of Anne Hutchinson and her followers. He realizes that to safeguard the very existence of his community as he sees it, he must confront and politically destroy the woman unless she agrees to recant. A trial is unavoidable, even necessary. His thoughts (expressed in the form of an aria) are counterpointed by choral sounds.

The stage opens up and we see a court scene, with Winthrop as the presiding judge, a court clerk, witnesses (a group of six ministers), men, women, and children of the community, and the soon to be accused: Anne Hutchinson.

Winthrop ends his soliloquy by instructing the clerk to call Anne Hutchinson before the court. This is done.

Here begins a series of exchanges between Winthrop and Anne Hutchinson. First the latter says little and Winthrop gets gradually frustrated by her clever and effective evasive actions. He comes close to losing his temper. These exchanges function as bouts between two skilled fencers who duel in the awareness that only one will leave the ground alive ... From time to time the audience (women and children) provides a background commentary. Their sung interventions, in their naiveté, contrast the life-death struggle of the protagonists.

Winthrop, feeling exasperated on account of his adversary, finally tries a new approach: he calls the ministers to testify. (They were, allegedly, berated by Anne Hutchinson on the ground of theological differences between her and them.) They voice their accusations in three closely co-ordinated interventions, which are, each time, denied by Anne Hutchinson, yet are appovingly echoed by the community, whose sung commentaries contribute to the constantly rising tension of the scene, leading to a powerful climax. This is abruptly cut short by the presiding judge, Winthrop, who came to realize that the testimony has produced no conclusive evidence that would prove guilt on Anne Hutchinson's part. 
Silence, heavy with meaning. It begins to be filled with children starting to sing timidly slogans of common wisdom learned in school, in absurd contrast with the tense situation at hand. Parents interrupt the children by uttering hushing sounds. Another pause, this time filled with excited, whispered, gossip of adults ... The stalemate continues ...

Suddenly Anne Hutchinson, sensing victory, rises and begins, unasked, a statement (an impassioned aria), telling about her feelings, her motivation and the thoughts that in her mind fully justify her activities, despite the censure of Winthrop and his group. In the end she makes a revelation that will prove to be her undoing. With this she gives the means by which she will be found guilty of unpardonable unorthodoxy by her adversaries and prosecutors.

Her testimony gives rise to an immense outburst of public indignation, which grows into the very climax of the entire composition. Her ensuing feverish self-defense and subsequent threats are of no avail. Winthrop is ready, and delivers the verdict, which is banishment from the colony. Crushed by the weight of the punishment (and by the concomitant perils it entails), Anne Hutchinson tries to utter a final plea, but receives no charity in response. She is destroyed, politically and socially, as well as being afflicted physically: she can hardly remain standing before her judge.

Winthrop, on his part, is paying a heavy price for committing this judicial act of destruction. He has to face up to the fact, that, to defend a utopia, or at least a status quo resembling in part a utopia that was, he lost a great deal of moral strength in the eyes of some of his contemporaries, in the perspective of history, and, what is most important, probably in his own view of himself. The price of defending Boston, as he conceived it, was to destroy a person with equally strong, but conflicting, views. In the course of the trial Winthrop aged much. This is conveyed by the addition of the "third Winthrop" (a bass) to the "second Winthrop" (a baritone) as he reads the verdict. The "first Winthrop" also joins them, to show the indivisibility of the "three ages" of the man.

As Anne Hutchinson hobbles out of the Meeting Hall one senses waves of compassion flowing toward her, timidly expressed, by parts of the chorus. Snatches of a psalm are sung softly ... then she takes a few more steps ... halts ... another psalm fragment ... another step or two ... and, finally, she disappears from sight ...

Rapid fade-out of light. 


\section{Interlude (Orchestra only)}

This section serves several purposes: first, to give a respite to the audience after the tension of the past forty-five minutes or so (Sections 7 and 8); second, to allow for a possible change of scenery; but, foremost, it represents both a nightmare of Winthrop's following the trial and the lapse of a dozen years.

The music is "seamless." Swirling clusters, in which faint, isolated sounds appear and disappear, persist throughout. All is very soft, restless, speaking of inner turmoil... After approximately three and one-half minutes this gradually clears away and without a break the next (final) section begins.

\section{Stocktaking}

The year is 1649 . The old Winthrop, sung principally by the bass, but also by the two earlier Winthrops (tenor and baritone), is ready to make an accounting (in part private, in part public) of his life and deeds. He appears to be, and is in reality, at peace with himself: a man who is aware of his accomplishments, as well as of his failures. The record he sees and tells about is a mixed and human one, and the three Winthrops, with a unified voice, show genuine humility and acknowledgment of frailty. As he reminisces about times of old, including those of danger, he is being echoed by "unseen" voices of the chorus. He reveals a strong religious feeling. Memories of personal battles come to mind. One senses that Winthrop still feels the scars of some of the fights of yesteryears. He is relieved that all those crises are over now ... He reveals a need for self-justification and gives a brief testimony to his beliefs concerning the nature of liberty and personal freedom...

One hears the first of several paeans sung in his honor. This is followed by others. The praises appear as farewells to an aging leader who is held in high esteem by the community. The last few snatches of trivial remembrances by Winthrop are heard, accompanied by a gently supporting chorus. One senses that Winthrop's life nears its end. A final sigh of relief from his threefold self before he dies ... A final paean, as if sung by angels, is heard . . . and the scene dissolves. The only instrumental sound remaining is that of a solo violin, playing an indifferent sequence. It accompanies the businesslike speaking voices of two auctioneers who, unseen, in the fading light, take stock of the modest estate Winthrop left behind, listing furniture, tools, old clothing, 
and other personal effects, together with such worthless items as glue ... The final stages of the fade-out of light and sound ... Complete darkness and silence.

\section{THE END}

